\title{
Lessons from Early REDD+ Experiences in the Philippines
}

\author{
Rodel D. Lasco, ${ }^{1}$ Neil Aldrin D. Mallari, ${ }^{2}$ Florencia B. Pulhin, ${ }^{1,3}$ Ailene M. Florece, ${ }^{1}$ \\ Edmund Leo B. Rico, ${ }^{2}$ Romnick S. Baliton, ${ }^{1}$ and Joan P. Urquiola ${ }^{1}$ \\ ${ }^{1}$ World Agroforestry Centre (ICRAF), 2nd Floor Khush Hall, International Rice Research Institute (IRRI), P.O. Box 35024, \\ Los Baños, Laguna 4031, Philippines \\ ${ }^{2}$ Fauna \& Flora International, Tagaytay City, Cavite 4120, Philippines \\ ${ }^{3}$ Forestry Development Centre, UPLB, Laguna, Los Baños, Laguna 4031, Philippines
}

Correspondence should be addressed to Rodel D. Lasco; rlasco@cgiar.org

Received 16 July 2012; Revised 23 February 2013; Accepted 30 March 2013

Academic Editor: Glenn Bush

Copyright (C) 2013 Rodel D. Lasco et al. This is an open access article distributed under the Creative Commons Attribution License, which permits unrestricted use, distribution, and reproduction in any medium, provided the original work is properly cited.

\begin{abstract}
There is growing interest globally in REDD+ initiatives to help mitigate climate change; the Philippines is no exception. In this paper, we review early REDD+ project experiences in the country. The guiding document for REDD+ in the Philippines is the National REDD+ Strategy (PNRPS) which was prepared by a multisectoral group of authors. There are five REDD+ projects that are underway. The critical factors emerging from these early REDD+ actions are the following: external support, local participation, free prior and informed consent, capacity building, sustainability, national laws and policies, biodiversity conservation, and use of safeguards. The pioneering projects reviewed here as well as the emerging lessons from them will hopefully provide a firmer basis for future REDD+ actions in the country.
\end{abstract}

\section{Introduction}

Land use, land use change, and forestry (LULUCF), especially tropical deforestation, are estimated to account for $1.6 \mathrm{Gt} \mathrm{C/yr}$ of anthropogenic emissions $[1,2]$ or around $17-20 \%$ of the total greenhouse gas emissions [3, 4]. More recent calculations have lowered this to $1.2 \mathrm{Gt} / \mathrm{yr}$ or about $12 \%$ of global emissions [5]. Despite its substantial contribution to total emissions, implementation of strategies to reduce LULUCF emissions is still in its infancy, especially in developing countries. The socioeconomic costs of these initiatives, such as alteration of livelihood practices, remain a challenge in crafting an effective strategy that would reduce emissions and address community benefits as well. Effective participation by affected local communities is essential in shaping the project success to reduce emissions [2]. A practical solution is to provide compensation to land managers and farmers for the opportunity costs of shifting land uses from high carbon stocked to lower ones, for example, not to clear forests for agriculture.

Carbon market, also known as cap and trade mechanism, enables nations to meet their mitigation targets by counting emission reductions even outside their national territory [6]. In the Philippines, there is a rising interest to participate in the emerging carbon market such as the Clean Development Mechanism (CDM) [7] and REDD+. Under CDM, developed or Annex I countries can achieve their mitigation targets by supporting emission-reducing projects in developing or nonAnnex I countries [6]. REDD+, on the other hand, is more specific. It refers to reducing emissions from deforestation and forest degradation, conservation of forest carbon stocks, sustainable management of forests, and enhancement of forest carbon stocks in developing countries [8]. The Cancun Agreements officially launched the REDD+ mechanism under the UNFCCC [9].

Several reforestation and agroforestry projects are under development in the Philippines in the last few years. However, none of these has been registered under the CDM Executive Board. The tedious and costly process of CDM discourages resource-poor proponents to engage in the activity [10]. There are also many sectors who now advocate participation in REDD+. REDD+ has a huge potential in the Philippines $[11,12]$. Communities hosting community-based forest 
management (CBFM) projects stand to gain under REDD+ as they have the most plausible tenurial instrument (e.g., Certificate of Ancestral Domain Title, Community-Based Forest Management Agreements, or Certificate of Stewardship) to implement an REDD+ project with respect to permanence of emissions reduction. However, this will vary depending on the REDD+ component [12]. CBFM sites contain forested areas or are near-forested lands. Local communities within CBFM sites can play a vital role in forest conservation. Under the avoided forest degradation component, CBFM communities could help reduce biomass loss from forests. Some communities gather wood from forests for their own use such as for timber and fuel wood which can be stabilized with the identification of a community production area for timber and fuelwood production. The communities can also serve as guardians of the forest to prevent outsiders from illegally cutting trees and thereby help lessen carbon loss. With activities that enhance carbon stocks, CBFM communities will have greater potential to earn carbon payments through such activities as assisted natural regeneration and agroforestry.

Since 2010, there have been efforts to start REDD+ projects in the Philippines. The objective of this paper is to review the initial REDD+ experiences in the Philippines and draw lessons from the challenges faced by pioneering projects. We draw our data from interviews with implementers of early REDD+ actions in the country as well as project documents and the existing literature.

\section{REDD+ Policies and Initiatives in the Philippines}

Prior to Spanish conquest, the Philippines was bestowed with abundant forests. Forests cover was about 90\% (27 million ha) of the total 30 million ha of the country's land area during the 1500s $[13,14]$. In the years following the Spanish conquest, significant conversion of forestlands into agriculture occurred. Further degradation of the forests happened during the American period because of the introduction of modern logging in the country. By 1900s, the area covered by forests was reduced to 20 million ha only [15]. From late 1950s to mid-1980s, large tract of forestland was awarded to timber licenses resulting in significant reduction of 11 forestlands of the country [16]. As of 2008, about 7 million ha of forests remain, around 1 million ha of which are oldgrowth forests while the remaining forestlands are in different states of degradation (Figure 1). The average deforestation rate from 1969 to 1973 was estimated to be 170,000 ha per year [17]. Another estimate put deforestation rate at 190,000 to 200,000 ha per year during the period 1977-1997 [18]. Drivers of deforestation include shifting cultivation, conversion to permanent agriculture, ranching, logging, fuel wood gathering, and charcoal making [19]. Although it is recognized that logging and agricultural expansion are the two major causes of deforestation, it is difficult to make assumptions due to severe data problems at the local level and lack of historical information [19]. The socioeconomic and environmental impacts of forest degradation include

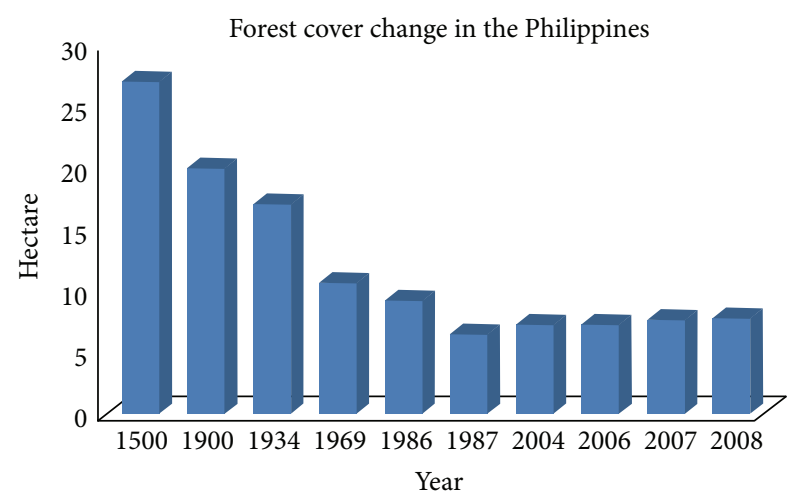

Figure 1: Forest cover change in the Philippines (data from official statistics of the Forest Management Bureau [60]).

widespread poverty, accelerated soil erosion, and massive flooding of low-lying areas [14].

Alongside the degradation of the forest resources is loss of huge amount of carbon and erosion of biodiversity of the country. The Philippines has one of the richest biodiversity resources in the world. It is in fact one of the world's 17 megadiversity countries [20-22]. However, many of its species are now threatened to become extinct. As of 2009, about 641 threatened species are in the IUCN Red List [23]. To conserve biodiversity, the main strategy of the government is through the implementation of the National Integrated Protected Area System (NIPAS) Law. As of 2004, there were already 99 declared protected areas with an aggregate area of 2.9 million hectares under NIPAS [24]. However, many of these declared protected areas remain to be paper parks and continue to be unprotected because of the insufficient financial resources and limited capacities for protected area management of the government [25].

Various sectors are currently preparing for the country's engagement in REDD+ mechanisms. On the government side, policies to support REDD+ implementation were developed. For example, REDD+ strategies were articulated in Chapter 7 (Synergy of Adaptation and Mitigation) of the National Framework Strategy on Climate Change (NFSCC) which has been approved by the president [26]. The NFSCC outlines the 12-year plan of the country as regards climate change mitigation and adaptation. In April 2010, Executive Order (EO) 881 was issued directing the Climate Change Commission (CCC) to coordinate climate change initiatives of the different sectors/agencies including REDD+ and other similar mechanisms. The same EO also designates the Department of Environment and Natural Resources (DENR) as the operational implementer of REDD+. Civil society organizations, in collaboration with government institutions, have spearheaded the development of the Philippine National REDD+ Strategy (PNRPS). In 2010, the PNRPS was prepared [27] and endorsed to CCC. Drafted by a pool of writers from various civil society groups, the academe, research institutions, local government units, and DENR, including its bureau representatives like the Forest Management Bureau (FMB), Ecosystems Research and Development Bureau 
Table 1: Projects related to REDD+ in the Philippines.

\begin{tabular}{|c|c|c|c|c|c|c|}
\hline Name & Location and area & Main implementer & Main sponsor & Duration & $\begin{array}{l}\text { Expected } \\
\text { carbon } \\
\text { benefits }\end{array}$ & Budget \\
\hline $\begin{array}{l}\text { (1) Climate-Relevant } \\
\text { Modernization of Forest } \\
\text { Policy and Piloting of REDD } \\
\text { in the Philippines }\end{array}$ & $\begin{array}{l}\text { Southern Leyte/31,848 } \\
\text { hectares }\end{array}$ & $\begin{array}{l}\text { Department of } \\
\text { Environmental and } \\
\text { Natural } \\
\text { Resources-Forest } \\
\text { Management Bureau } \\
\text { (DENR-FMB ) }\end{array}$ & $\begin{array}{l}\text { German } \\
\text { Agency for } \\
\text { International } \\
\text { Cooperation } \\
\text { (GIZ) }\end{array}$ & $\begin{array}{c}\text { October } \\
\text { 2010-March } \\
2013\end{array}$ & $\begin{array}{l}42 \text { tons of } \\
\text { carbon per } \\
\text { year }\end{array}$ & 2.7 M euros \\
\hline $\begin{array}{l}\text { (2) Advancing Development } \\
\text { of Victoria-Anepahan } \\
\text { Communities and Ecosystem } \\
\text { through REDD (ADVANCE } \\
\text { REDD) }\end{array}$ & $\begin{array}{l}\text { Southern } \\
\text { Palawan/50,000 } \\
\text { hectares }\end{array}$ & $\begin{array}{l}\text { Non-Timber Forest } \\
\text { Products-Task Force } \\
\text { (NTFP-TF) } \\
\text { Fauna \& Flora } \\
\text { International } \\
\text { Philippines (FFI) }\end{array}$ & $\begin{array}{l}\text { European } \\
\text { Union (EU) }\end{array}$ & Not specified & Not specified & $0.4 \mathrm{M}$ euros \\
\hline $\begin{array}{l}\text { (3) Community Carbon Pools } \\
\text { Programme (C2P2) }\end{array}$ & $\begin{array}{l}\text { Southern Sierra } \\
\text { Madre mountain } \\
\text { range in Quezon } \\
\text { Province, } \\
\text { Luzon/144,000 } \\
\text { hectares }\end{array}$ & $\begin{array}{l}\text { Fauna \& Flora } \\
\text { International } \\
\text { Philippines (FFI) } \\
\text { Non-Timber Forest } \\
\text { Products Task Force } \\
\text { (NTFP-TF) } \\
\end{array}$ & $\begin{array}{l}\text { European } \\
\text { Union (EU) } \\
\text { Team Energy } \\
\text { Foundation } \\
\text { Inc. }\end{array}$ & $\begin{array}{c}\text { March } \\
2010-2014\end{array}$ & No estimates & $\begin{array}{l}0.4 \mathrm{M} \text { euros } \\
\quad \text { (initial } \\
\text { funding) }\end{array}$ \\
\hline $\begin{array}{l}\text { (4) Quirino Forest Carbon } \\
\text { Project-Quirino Province, } \\
\text { Luzon Island, Philippines }\end{array}$ & $\begin{array}{l}\text { Quirino Province/177 } \\
\text { hectares }\end{array}$ & $\begin{array}{l}\text { Conservation } \\
\text { International (CI) }\end{array}$ & $\begin{array}{l}\text { MoreTrees, } \\
\text { Inc. } \\
\text { (Japan-based } \\
\text { organization) }\end{array}$ & $2009-2029$ & $\begin{array}{l}31,771 \text { tCO } 2 \mathrm{e} \\
\text { in } 23 \text { years. }\end{array}$ & $\begin{array}{l}\text { USD } 287,000 \\
\text { (initial) }\end{array}$ \\
\hline $\begin{array}{l}\text { (5) Philippine Peñablanca } \\
\text { Sustainable Reforestation } \\
\text { Project }\end{array}$ & $\begin{array}{l}\text { Peñablanca, } \\
\text { Province/2,943 } \\
\text { hectares }\end{array}$ & $\begin{array}{l}\text { Conservation } \\
\text { International (CI) }\end{array}$ & $\begin{array}{l}\text { Toyota Motor } \\
\text { Corporation } \\
\text { (TMC) }\end{array}$ & $\begin{array}{c}30 \text { years } \\
\text { (actual years } \\
\text { not specified) }\end{array}$ & $\begin{array}{c}362,920 \\
\text { tCO2e in } 30 \\
\text { years }\end{array}$ & $\begin{array}{c}\text { USD } 2.7 \mathrm{M} \\
\text { over six years }\end{array}$ \\
\hline
\end{tabular}

(ERDB), Parks and Wildlife Bureau (PAWB), National Commission on Indigenous People (NCIP), and National Mapping, and Resource Information Authority (NAMRIA), the PNRPS offers a number of strategies and corresponding activities over a 10-year time period (2010-2020). The PNRPS has seven components: (1) enabling policies; (2) governance; (3) resource use, allocation and management; (4) research and development; (5) measurable, reportable and verifiable (MRV) conditions; (6) capacity building and communication; and (7) sustainable financing. In recognition of REDD+'s significance in the overall national climate change mitigation effort, the National Framework Strategy on Climate Change of 2010 included the national REDD+ Strategy as one of its key result areas for mitigation [28]. Further in 2011, the National Climate Change Action Plan adopted the Philippine REDD+ Strategy as its main activity to enhance resilience and stability of natural systems and communities [29].

\section{REDD+ Project Experiences}

The Philippines is more actively engaged in pilot testing $\mathrm{REDD}+$ in the country compared with CDM. In this section, we describe and analyze the initial REDD+ projects. Table 1 summarizes the characteristics of five pilot REDD+ projects by different organizations. These projects are in various stages of development, ranging from conceptualization to early phase of implementation. The first three projects were established as REDD+ pilot projects. These projects are noted as ongoing demonstration sites in the PNRPS.

The two projects of Conservation International (CI) Philippines are within the Sierra Madre mountain range which is the longest mountain range in the country where the largest old-growth tropical rainforest tracts remain. Though Sierra Madre range is declared as a protected area by the government, environmental threats from human activities, such as forest conversion, mining, and timber poaching, continue to degrade much of the area, resulting in forest loss and watershed degradation. The projects of CI Philippines in the area aim to create alternative livelihood to the local community, to protect and improve the habitats for plants and animals, and to enhance ecological services such as watershed functions for steady provision of water. The projects were initially intended as a forestry carbon project under the Clean Development Mechanism (CDM). However, CDM only allows afforestation and reforestations for forestry projects and does not give much emphasis on socioeconomic or noncarbon benefits to the community; thus the projects of CI focus more on reforestation and agroforestry establishment on parcels of land volunteered by the local communities.

The Peñablanca Sustainable Reforestation Project (PSRP) and the Quirino Forest Carbon Project (QFCP) were the first projects in the Philippines to pass the Climate, Community and Biodiversity (CCB) Standards in 2009, earning a Gold 
Standard for integrating community and biodiversity benefits in the project implementation. In 2011, the QFCP was the first in the country to be accredited under the Verified Carbon Standards (VCS) program, one of the main global standards and quality assurance system for accounting of greenhouse gas (GHG) emission reduction in the voluntary carbon market. With the VCS accreditation of QFCP, it can be assumed that the CI projects are very much veering into the voluntary carbon market. There is also the possibility of scaling up the projects to REDD+, noting that the sites have protected forest covers which cannot be included under CDM. We included them in this review even if it is not yet certain whether they will become REDD+ projects because the lessons they have generated could be valuable going forward with REDD+ in the country.

Geographically, all the projects are in Luzon and Visayas islands with none in the southern island or Mindanao. In terms of forest land management, most projects include reforestation and agroforestry components which also fall under the CDM. This is due to the prevalence of denuded open lands in project sites. There is also strong emphasis on capacitating stakeholders, particularly in terms of forest project planning, management, monitoring and evaluation, and other technical and management skills needed to ensure the sustainability of the projects. Some projects have estimated the amount of carbon to be sequestered, which could be an indication of the project's readiness in entering the carbon market, or the level of technical skills and know-how provided by the implementers in their project areas. Some projects, aside from reforestation activities, are also conducting studies on Philippine forest policies, drivers of deforestation and forest degradation, carbon rights, and assessment of free prior and informed consent (FPIC) implementation. In terms of funding, most of them are supported by foreign donors such as the GIZ and EU.

\section{Lessons Learned}

REDD+ activities in the Philippines are experiencing almost the same problems as other countries readying for REDD+, that is, conflicting and weakly enforced forest policies, lack of knowledge and involvement of local people, tenurial conflicts and insecurity, and absence of proper accounting and MRV system among other issues [30-32]. In this section, we distil the lessons emerging from the early implementation of REDD+ activities in the Philippines. These lessons, as presented in Table 2, were gleaned from interviews with project participants as well as review of relevant documents. Positive and negative characters on the table denote strengths and weaknesses, respectively.

4.1. External Support. All projects reviewed were being funded and/or implemented by at least one international organization. This shows that an important driver for early REDD+ action in the Philippines is external financial and technical support. External financial and technical support pushes preparatory REDD+ activities, such as introduction, capacity building and engagement of stakeholders, assessment of drivers of deforestation, and piloting of REDD+ sites. These activities adhere to the first phase, or the readiness phase, of the 3-phase approach suggested in the 2009 Meridian Report [33], an approach which PNRPS also followed. The second phase involves development of national policy framework for the implementation of REDD+; while third phase will focus on the full implementation of REDD+ activities with actual performance-based payment mechanism established.

As in many countries, the challenge is how to finance preparatory activities before funds from REDD+ carbon credits become available hopefully during Phase 3 of the 3 phase approach. REDD+ requires significant funding to get the technical, policy, and implementation elements together and up to par with the global standards. Globally, it is not yet clear how REDD+ can be supported sustainably in the long run. The United Nations Framework Convention on Climate Change (UNFCC) will have to reach a legally binding post-2012 climate agreement that would determine whether REDD+ will be financed through fund-based, market-based, or a combination of the two financial resources. For now, initiatives are currently being financed by international organizations, assisted on ground by local NGOs and government units.

Because REDD+ is quite a new mechanism in the Philippines, even the early adopters struggled a lot, especially with the kind of expertise that is needed to deliver the various components of REDD+. For instance, in the preparation of the PNRPS which was spearheaded by the civil society groups, support from international donors was needed. Likewise, in capacity building activities that will help prepare the country in REDD+ implementation, the Philippine government had to rely on the grant given by the UN-REDD Programme amounting to USD 500,000. Although the government, both local and national level, seemed supportive of REDD+ initiatives and are, in fact, important stakeholders of the projects listed in this paper, they were not exactly seen much at the forefront of activities, particularly during the initial introduction of REDD+ in the country. Efforts by the civil groups were recognized and supported by the DENR and the Philippine Climate Change Commission (CCC); however, these actions from the national government only materialized around the time of the validation of the PNRPS.

One possible reason for the government's passive role is that unlike the CDM which requires national-level management and monitoring and intergovernmental transactions and collaborations, REDD+ is still a voluntary mechanism and currently has no binding international agreement to encourage action from the government sector. As such, the role of the government in REDD+ implementation in the country is not yet clear.

Although the government poses a more active role in implementing CDM in the country, it should be noted that, as of May 31, 2012, none of the projects registered at the CDM executive board are under the forest category [34]. It seems that there is no incentive for the government to engage in forestry carbon projects, whether it is under CDM, the voluntary carbon market, or possible REDD+ financing mechanism. At the same time, it should also be noted 
TABLE 2: Summary of strengths and weakness of projects related to REDD+.

\begin{tabular}{|c|c|c|c|c|c|}
\hline Critical factors & 1 & 2 & 3 & 4 & 5 \\
\hline $\begin{array}{l}\text { (1) External } \\
\text { support }\end{array}$ & $(+) \mathrm{GIZ}$ & $(+) \mathrm{EU}$ & $(+) \mathrm{EU}$ & (+) MoreTrees, Inc. & $(+) \mathrm{TMC}$ \\
\hline $\begin{array}{l}\text { (2) Local } \\
\text { participation }\end{array}$ & $\begin{array}{l}\text { (+) POs are actively } \\
\text { participating } \\
(-) \text { Nonavailability of } \\
\text { local counterpart funds } \\
\text { caused delay of } \\
\text { activities }\end{array}$ & $\begin{array}{l}\text { (-) In conflict with the } \\
\text { interests of local } \\
\text { government units } \\
\text { (LGUs) which } \\
\text { prioritize mining } \\
\text { applications }\end{array}$ & $\begin{array}{l}\text { (+) Indigenous peoples } \\
\text { community actively } \\
\text { participating } \\
(-) \text { Complex } \\
\text { arrangements since the } \\
\text { project covers several } \\
\text { provinces }\end{array}$ & $\begin{array}{l}\text { (-) Issue on benefit } \\
\text { sharing }\end{array}$ & $\begin{array}{l}\text { (-) Conflicting with } \\
\text { LGU's interest }\end{array}$ \\
\hline $\begin{array}{l}\text { (3) Free prior } \\
\text { and informed } \\
\text { consent }\end{array}$ & Not applicable & $\begin{array}{l}\text { (-) Spent more than a } \\
\text { year to secure the FPIC }\end{array}$ & $\begin{array}{l}\text { (-) Spent almost a year } \\
\text { to secure community } \\
\text { endorsement/FPIC }\end{array}$ & Not applicable & Not applicable \\
\hline $\begin{array}{l}\text { (4) Training of } \\
\text { stakeholders }\end{array}$ & $\begin{array}{l}\text { (+) Capacity } \\
\text { development of DENR, } \\
\text { LGUs and partners }\end{array}$ & $\begin{array}{l}(+) \text { Community } \\
\text { training on carbon } \\
\text { mensuration and } \\
\text { biodiversity assessment } \\
(+) \text { LGU as one of the } \\
\text { partner implementer }\end{array}$ & $\begin{array}{l}\text { (+) Able to develop } \\
\text { community REDD+ } \\
\text { champions } \\
\text { (+) Capacity building } \\
\text { of LGUs, IPs, and other } \\
\text { stakeholders involve }\end{array}$ & $\begin{array}{l}(+) \text { Community } \\
\text { capacity building }\end{array}$ & $\begin{array}{l}(+) \text { Community } \\
\text { capacity building }\end{array}$ \\
\hline $\begin{array}{l}\text { (5) } \\
\text { Sustainability }\end{array}$ & $\begin{array}{l}\text { (+) Alternative } \\
\text { livelihood }\end{array}$ & $\begin{array}{l}(+) \text { Enterprise and } \\
\text { infrastructure } \\
\text { development aid }\end{array}$ & $\begin{array}{l}\text { (+) Provision of } \\
\text { livelihood and } \\
\text { enterprise development } \\
\text { activities. } \\
(+) \text { Integration of } \\
\text { REDD+ in the } \\
\text { Ancestral Domain } \\
\text { Sustainable and } \\
\text { Development Plan }\end{array}$ & $\begin{array}{l}\text { (+) Establish } 22 \text { ha } \\
\text { of agroforestry } \\
\text { from which the } \\
\text { local communities } \\
\text { derive additional } \\
\text { income and } \\
\text { improve the } \\
\text { long-term } \\
\text { productivity of } \\
\text { their farms }\end{array}$ & $\begin{array}{l}\text { (+) Alternative } \\
\text { livelihood through } \\
\text { reforestation, } \\
\text { enhancement planting, } \\
\text { and agroforestry }\end{array}$ \\
\hline $\begin{array}{l}\text { (6) National } \\
\text { laws and } \\
\text { policies }\end{array}$ & & $\begin{array}{l}\text { (-) RA 7942: } \\
\text { Philippine Mining Act } \\
\text { of } 1995 \text { (persistence of } \\
\text { mining/mineral } \\
\text { development zone } \\
\text { despite the existence of } \\
\text { policy framework on } \\
\text { forest conservation and } \\
\text { governances) }\end{array}$ & $\begin{array}{l}(-) \text { Tenurial conflict } \\
(-) \text { various national } \\
\text { statutes in place (e.g., } \\
\text { IPRA, NIPAS and } \\
\text { Local Government } \\
\text { Code) }\end{array}$ & & (-) Tenurial conflict \\
\hline $\begin{array}{l}\text { (7) Biodiversity } \\
\text { conservation }\end{array}$ & $\begin{array}{l}\text { (+) Protection of } \\
5,000 \text { ha natural forests } \\
\text { and establishment of } \\
2,000 \text { ha species-rich } \\
\text { reforestation }\end{array}$ & $\begin{array}{l}(+) \text { Protection of key } \\
\text { biodiversity areas }\end{array}$ & $\begin{array}{l}(+) \text { Protection of key } \\
\text { biodiversity areas }\end{array}$ & $\begin{array}{l}(+) \text { Reforestation } \\
\text { of } 155 \text { ha with } \\
\text { indigenous species } \\
\text { suitable to bring } \\
\text { back forest } \\
\text { condition and } \\
\text { appropriate } \\
\text { biophysical } \\
\text { requirement of the } \\
\text { site }\end{array}$ & $\begin{array}{l}\text { (+) Reforestation using } \\
\text { indigenous forest tree } \\
\text { species } \\
\text { (+) Distribution of } \\
\text { efficient rice hull and } \\
\text { firewood stoves and } \\
\text { fuelwood plantation } \\
\text { development were also } \\
\text { included in the project } \\
\text { to help reduce } \\
\text { deforestation. }\end{array}$ \\
\hline $\begin{array}{l}\text { (8) Use of } \\
\text { safeguards }\end{array}$ & $\begin{array}{l}(+) \text { Community-Based } \\
\text { Forest Management } \\
(\text { CBFM })\end{array}$ & $\begin{array}{l}\text { (+) IPRA and SEP } \\
\text { clearance }\end{array}$ & $\begin{array}{l}\text { (+) IPRA and } \\
\text { DENR-PAWB GP }\end{array}$ & $\begin{array}{l}\text { (+) Community- } \\
\text { Based Forest } \\
\text { Management } \\
(\text { CBFM) }\end{array}$ & \\
\hline
\end{tabular}

Legand

(1) Climate-relevant Modernization of Forest Policy and Piloting of REDD in the Philippines.

(2) Advancing Development of Victoria-Anepahan Communities and Ecosystem through REDD (Advance REDD).

(3) Community Carbon Pools Project (C2P2).

(4) Quirino Forest Carbon Project.

(5) Philippine Penablanca Sustainable Reforestation Project. 
that the government, as represented by DENR, is involved in three of the projects reviewed and has continued to recognize and support efforts of other organizations in their work on REDD+. Another possible reason for the passive role of the government in these forestry carbon projects is the country's greater emphasis on adaptation rather than mitigation measures, as stated in the National Climate Change Action Plan (NCCAP) 2011-2028 [35], due to the country being an insignificant emitter of carbon and being one of the most vulnerable countries to the effects of climate change. The NCCAP also recognizes the potential of carbon markets, which include future REDD+ financing mechanism, as a source of adaptation financing. Thus, it is expected that the Philippine government will hold a more active stance in carbon projects and REDD+ in the future.

4.2. Local Participation. A very important component of REDD+ is the participation of local communities living near or within the project sites. Local participation helps project proponents in designing activities to fit the needs of the local community and, at the same time, avoid conflicts and resistance [36]. Project introduction, solicitation of consent, and cooperation building are some of the most critical and time-consuming initial activities needed to be done in order to facilitate the involvement of the communities. However, these same activities had caused delays in all the project sites, with some having longer delays than others due to uncooperative communities, logistic and administrative issues, conflicting personal interest of stakeholders, and social opposition to REDD+ due to cultural beliefs and anticommercialism sentiments.

For example, complex arrangements, policies, and procedures of government units are some of the major sources of problems, particularly in project sites that cover multiple areas and towns such as the Fauna \& Flora International Philippines (FFI Philippines) project site in the Southern Sierra Madre Mountain Range which spans across four provinces. The time to convene and transact with officials and representatives from different towns and provinces can be a tedious and expensive process. Further, in FFI's project site, conflicts arise from non recognition of the IPs ancestral domain by the local government unit and vice versa with the IPs nonrecognition of the forest land use plan crafted by the local government unit of General Nakar. The opposing views of these major stakeholders over the ownership or the right to manage the land hampered the implementation of capacity building activities and assessments as arising issues are carefully managed first prior to implementing any activity. Managing this relationship issue of these stakeholders ate up a significant amount of project time.

In another case, payments and benefits from REDD+ are not enough to convince the community to forfeit opportunity cost, as in the case of Berong, Quezon in Palawan wherein the local government officials decided to choose mining instead of participating in the REDD+ demonstration project of the Non-Timber Forest Products Tasks Force (NTFP-TF). Based on an interview, deliberate amendment of ordinances for environmentally critical areas is done by local policymaker to accommodate mining operations. Moreover, it is difficult to develop an effective forest governance mechanism and benefit-sharing arrangement for future carbon revenues due to culture of corruption.

Cultural beliefs and anticommercialism sentiments were also cited as reasons for some communities to oppose REDD+. There are those who disagree with the commodification of carbon, saying that forest conservation and rehabilitation are the responsibility of the government and community. The commodification of carbon is believed to also take away the responsibility from developed countries who are heavy emitters of GHG by dispersing efforts and making developing countries do activities that the developed countries should be doing.

Participation is critical particularly at the initial phase, and important all throughout the duration of the project to facilitate better communication, coordination, and reduction of possible problems and conflicts in the project. Community involvement, coupled with security of tenure and access to forest resources, fosters a sense of forest ownership and greater commitment to forest protection efforts of the local people [37], and increases the chance of the project to become sustainable.

4.3. Free and Prior Informed Consent (FPIC). As mandated by law, an FPIC certificate needs to be secured from the National Commission on Indigenous People (NCIP) if the project area overlaps with indigenous domain. FPIC is fundamental in getting the communities and indigenous people to embrace REDD+ and the activities related to it.

A REDD+ project is a departure from a "business-asusual scenario" where the drivers of deforestation and degradation will be avoided. This means that the forest-dependent communities must find alternative livelihoods that will not result in deforestation and forest degradation and, if possible, will contribute to the maintenance, conservation, and improvement of the forest. It is essential that the whole community takes part to ensure that the goals of the project shall be delivered for the long haul. Thus it is important that the communities at the grassroots level understand and agree with the objectives of REDD+ regardless of the length of time involved in the process of soliciting their participation; otherwise, the project will isolate the very people it tries to help [38].

Securing FPIC certification is also one of the chief causes of delay in the implementation of an REDD+ project. The process of getting a certificate may take a minimum of 70 days and could even take about a year or more to finish. The process could be further aggravated by the size of project area or if it encompasses several local communities, as this will prove expensive and tedious during the conduct of meetings with the communities. In the case of FFI Philippines, after at least 10 months of work to secure the Agta communities' consent, the team had to wait for additional months to finally work on the processing of the issuance of the Certificate of Precondition (CP) from the NCIP. The NCIP has yet to issue the $\mathrm{CP}$ for the project. 
Similarly, the Advance REDD project of NTFP-EP spent almost a year to accomplish the consent of the communities. A lot of time is being spent on convening with the communities and processing of $\mathrm{CP}$ alone. There is also the possibility of the community not consenting to the project; thus implementers could either spend more time to convince the community or find some other area to work with.

4.4. Training of Stakeholders. Designing and implementing an REDD+ project requires a lot of technical skills such as proposal making, nursery establishment and management, data gathering, community organizing, monitoring and evaluation, and livelihood skills for community development. Familiarization with the UN Framework Convention on Climate Change (UNFCCC), Executive Board (EB) updates on Project Design Documents (PDD), Clean Development Mechanism (CDM), Voluntary Carbon Standards (VCM), Climate, Community, and Biodiversity (CCB) processes, and prescriptions and requirements is also needed. Project implementers train local community members on the basics of these skills to enable them to participate and to help in the management and monitoring of the project. Enabling the community members to participate can reduce reliance on external experts and, consequently, reduce operational cost of the project while providing them with additional livelihood [39]. It is not surprising that the initial stages of project implementation tended to be capacity-building intensive. Additionally, developing community REDD+ champions has been worthwhile in the Southern Sierra Madre pilot but it has taken the project significant amount of time to develop key individuals from the local communities. Community champions are individuals and organizations who live or are embedded in the community and who support the benefits and potentials of REDD+ to the community. These champions are important to help sustain REDD+ advocacy within the community by helping implementers in their activities and promoting the project to others. Considering that main implementers of most of the REDD+ projects reviewed in this paper are based from outside the project areas, REDD+ champions are needed in order to maintain the momentum of REDD+ advocacy within the sites.

On the negative side, convening local people, assessing the basic skills needed, and finding resource persons who will teach may take a long time. There is also the issue of differing skills and capabilities of individuals of the community. In some cases, educated affluent groups in the community may have more to gain in projects, than, say, poor uneducated individuals. This scenario may lead to elite capture, if affluent class, particularly the local leaders, are to gain leverage by having more access to resources and influence over the project. Elite capture has been noted in some projects in the Philippines, particularly in areas where there is high socioeconomic inequality and individuals in the community are not well organized [40,41]. Donors and implementers of projects are advised to utilize project design as a tool to prevent elite capture by reinforcing community participation, highlighting goals and accountability, and establishing monitoring and evaluation procedures in the design [42].
On the downside, if technical and managerial responsibilities are to be given to individuals with poor educational background and skills, then there might be the possibility of lowquality work output, which may prove to be a problem particularly with activities requiring high levels of technical skills (i.e., carbon stocktaking, monitoring and evaluation). Project implementers would have to clearly assess the different levels of skills present in the community in order to determine whether it would be better to conduct further trainings or to outsource the skills needed, as dictated usually by the presence of funds and allotted timeframe given.

Regardless of the time and resources consumed, capacity development is still needed to strengthen local forest protection and management capabilities and facilitate the decentralization of resource management responsibilities to the local community level. The involvement and training of local communities are considered effective strategies for REDD+, since these actions have proven to solve many of the local drivers of deforestation as well as provide a cost-effective alternative in conducting carbon monitoring and inventory, as shown in REDD+ pilot cases in Cambodia [37], in Mexico, and Tanzania [39].

4.5. Sustainability. For projects that have gone through the initial stages and are currently in the implementation and monitoring phase, such as the Quirino and Peñablanca projects of CI, the next logical step would be to continue, maintain, and possibly expand the project. Projects do not last forever; if livelihoods are dependent on them, chances are people may revert to their old destructive practices eventually, thus possibly rendering the project a failure. It is important that the changes brought about by the project in the lives of the community are maintained or improved through time, particularly if the development aims to ensure environmental sustainability. Communities living near the area are an important aspect of the dynamics of the environment and can either be a positive or negative factor in the continuation of REDD+ [43].

The inclusion of cobenefits is seen as one of the possible solutions to the problem of sustainability of REDD+. Cobenefits pertain to the additional benefits, other than climate mitigation, that can be derived from the implementation of improved forest management and conservation through REDD+ [44]. These co-benefits may appear in the form of socioeconomic and livelihood benefits, and biodiversity conservation, and improvement of ecosystem services such as watershed protection and reduced soil erosion. Four out of five projects reviewed, aside from providing technical assistance and conducting activities to improve environmental services and carbon stocks, also focused in providing livelihood programs to the community that will help them augment their income or convince them to convert from destructive to nondestructive activities. The REDD+ demonstration sites of the NTFP-TF and FFI Philippines provide enterprise and infrastructure development aid to the community, such as improving water facilities and constructing a honey processing center. The projects continue to help the community amidst some opposition against REDD+ 
from certain groups in the community. In the case of CI projects, the co-benefits came in the form of additional income from the products and crops derived from the trees planted in the reforestation and agroforestry farming, as well as distribution of efficient rice hull stoves to the community and development of fuelwood plantation.

4.6. National Laws and Forest Policies. While the CCC and the DENR have recognized the potential of REDD+ through the National Framework Strategy on Climate Change (NFSCC) by including the implementation of the PNRPS as one of the activities in the 2011-2028 National Climate Change Action Plan (NCCAP), REDD+ has yet to be fully mainstreamed at the national level. The government has yet to bring down these policies and actions at the subnational level. Currently, the government has been helping the local government units (LGUs) in developing their Local Climate Change Action Plan (LCCAP) as mandated by the Climate Change Act of 2009, as well as initiating the implementation of the NCCAP. But more concrete actions on climate change and REDD+ are yet to be seen.

Another main issue is the lack of cohesion in forest policies, laws, and roles of departments/units within the government, a problem that persists in a lot of countries implementing REDD+ [45]. Though CCC and DENR have been moving to resolve the issue, it will still take a while to streamline policies and departments, particularly laws that may greatly affect implementation of REDD+ such as the Mining Act of the Philippines and land tenure policies.

National laws and policies are needed in order to strengthen the legal framework of REDD+ implementation to enhance links of local communities to various government and nongovernment agencies for REDD+ financing and collaboration, facilitate the implementation of the REDD+ or forestry carbon projects, and ease the minds of potential investors. Such are the reasons why all of the projects include in their component support at the national level to push enabling laws for REDD+ and forest policy reforms.

4.7. Biodiversity Benefits as an Integral Part of REDD+. REDD+ actions may have positive and/or negative effects to biodiversity [46].

The PNRPS considers a triple currency: carbon, biodiversity, and community. In essence, the PNRPS is not only focused on carbon sequestration and valuation, but it also pays equal attention to conservation of biodiversity and improvement in local community. These follow logically from two considerations. First, the Philippines harbors one of the richest biodiversity resources in the world. The country is one of the megabiodiversity countries due to its geographical isolation, diverse habitats, and high rates of endemism. Based on The 4th Philippine National Report to the Convention on Biological Diversity [47], the Philippines contains $2 / 3$ of the earth's biodiversity and about $70-80 \%$ of the world's plant and animal species. Also, the country ranks 5 th in the number of plant species and maintains 5\% of the world's flora. At the same time, the Philippines is also considered as one of the world's biodiversity hotspots because of the large number of endangered and threatened species and habitats which makes it one of the world's conservation priority areas.

Second, the Philippine uplands, where most of the remaining forests are located, are also home to perhaps up to 20 million people who belong to the poorest class. There seems to be little chance of relocating these people outside forest lands (such as areas designated for forest cover even if most of them have no forests today). Even protected areas are inhabited by throngs of people. Many of the upland communities including indigenous peoples rely on forests and agriculture for their livelihoods. Thus, success of REDD+ hinges to a great extent on providing alternative sustainable livelihoods to local settlers.

Globally, current carbon sequestration schemes, including REDD+ initiatives, are mostly focused on carbon and trees. Such focus was noted in some studies $[48,49]$ to have potential detrimental effects on the overall biodiversity of the forest, particularly since forest conservation and carbon sequestration projects are primarily designed for protection and rehabilitation of timber trees and have little to no mechanism or activities devoted to protection of animals and nontimber species. Although carbon sequestration programs suggest "taking into account" environmental impacts on biodiversity and natural ecosystems, such vague wordings cannot be interpreted as concrete directives to include biodiversity concerns in the projects. There is the possibility that REDD+ projects, with its focus on carbon sequestration, may compel communities or implementers to only protect and plant timber species that store high volume of carbon and disregard other plants or tree species. If this happens, then REDD+ projects in the Philippines may disrupt the very biodiversity the country is trying to protect. All these unchecked aspects in REDD+ initiatives may eventually result in biodiversity loss, which, in turn, affects also the resiliency of the ecosystem. Ecosystem resiliency pertains to the ability of the forest ecosystem to recover from unpredictable disturbance such as fires, natural disasters and invasive species. Forests with high levels of biodiversity are more resilient and have greater chance of recovery and are therefore more adaptable to climate change and are able to continue storing carbon for a long time [50].

Also, issues such as poaching or excessive hunting are not given much attention. This is in light of the recent studies that bush meat hunting of selected species, which act also as seed dispersers, is directly connected to the shifting in tree species composition of forest in countries such as Thailand, Cameroon, and Panama [51-53]. It was discovered that 70$90 \%$ of tree species rely mostly on these hunted animals for seed dispersal. The studies in Cameroon and Thailand have also linked the removal of large-bodied seed dispersers to the loss of larger tree species that store high amounts of carbon.

Co-benefits for biodiversity and community, which may or may not directly involve carbon sequestration but will affect the overall function of the ecosystem, should also be included in the design of REDD+. However, current standards, such as that of the Climate, Community and Biodiversity Alliance (CCBA), include indicators that are mainly related to forest carbon stocks. While it presents a system of checklist of biodiversity impacts, it does not 
consider other biodiversity determinants of species presence or abundance that are not, in any way, related to just forest carbon stocks, such as hunting or decline of population of prey species outside the REDD forest areas or crash in the breeding cycle despite studies that linked biodiversity changes to carbon sequestration [54].

If the Philippines intends to stick to the triple currency, they will also need to recalibrate the methods in quantifying impacts of avoided deforestation. These methods should quantify the positive and negative impacts of deforestation, considering that biodiversity is one of the major environmental concerns of the country.

4.8. Use of Safeguards. The Cancun Agreements specify the systems and information that developing countries need to have in order to undertake REDD+ activities. One of these is a system for providing information on how safeguards are being addressed and respected throughout the implementation of REDD+ activities, while respecting national sovereignty [55]. "Safeguards" is often used in reference to measures, such as policies or procedures, designed to prevent undesirable outcomes of actions or programmes [56]. They aim to address both direct and indirect impacts to communities and ecosystems by identifying, analyzing, and ultimately working to mitigate risks [57]. They also provide a mechanism for consultation and disclosure of information.

Safeguards have been a contentious topic in the REDD+ debate. Some argue that safeguards could potentially make implementation of REDD+ more complex and expensive and therefore less able to compete with other land uses, or with other sources of carbon credits [56]. On the other hand, others argue that the safeguards do not go far enough to protect the culture and livelihood of forest-dependent communities. The policies and mechanisms to ensure these safeguards are effectively addressed are not yet fully developed. A Subsidiary Body for Scientific and Technological Advice (SBSTA) work programme is in place over the next year to develop guidance on a system for providing information on how safeguards are being addressed and respected, while considering national sovereignty.

Uncertainty in how safeguards are to be addressed could slow down the negotiation process and the implementation of REDD+ activities. A cost-effective way to do this is to adapt existing national safeguards for forestry projects. However, there is lack of knowledge on how existing national safeguards can be used for REDD+ implementation.

Many developing countries have existing national safeguards related to forestry projects and activities. In the Philippines, the existing national safeguards include the Philippine Environmental Impact Statement System (PEISS), Community- Based Forest Management (CBFM), Philippine Strategy for Sustainable Development, Indigenous Peoples Rights Act, Wildlife Resources and Conservation Act, and Strategic Environmental Plan for Palawan Act. These relevant national safeguards can serve as the starting point in the formulation of safeguards specifically for REDD+. The PEISS is the most important institutional mechanism that addresses biophysical and socioeconomic safeguards of forestry projects, among others. Forestry projects are classified under environmentally critical projects and therefore require a full-blown environmental impact assessment (EIA). In addition, most forestry projects (including REDD+ projects) are located in environmental critical areas which require the conduct of EIA. The EIA process explicitly requires consideration of socioeconomic impacts to indigenous peoples and women. Community-Based Forest Management (CBFM) as a national strategy in upland development is also guided by environmental and socioeconomic safeguards such as those related to property rights. There also exists a Philippine Strategy for Sustainable Development which contains indicators that can be used as a basis in forming safeguards for REDD+ projects.

The Indigenous Peoples Rights Act of 1997 (Republic Act 8371) stipulates in Section 17 Chapter 4 (The Right to Self-Governance and Determination) that "the IPs shall have the right to determine and decide their own priorities for development affecting their lives, beliefs, institutions, spiritual well-being, and the lands they own, occupy or use. They shall participate in the formulation, implementation, and evaluation of policies, plans, and programs for national, regional, and local development which may directly affect them." Hence, its implementing rules and regulation articulates, that a proponent of a policy, plan, project or programme affecting an indigenous people's community or an entire ancestral domain shall be required to secure a free and prior informed consent (FPIC). Such that in the process of securing the FPIC, the IP communities shall have full disclosure of the project's activities, impacts and the responsibilities of all parties involve.

In terms of safeguarding biodiversity, the Philippines has its Wildlife Resources and Conservation Protection Act (Republic Act 9147). The act provides the conservation and protection of wildlife species and their habitats to promote ecological balance and enhance biological diversity, the regulation in the collection and trade of wildlife to carry out the Philippines commitment to international conventions, and the instigation or assistance in scientific studies on the conservation of biological diversity.

Unique to the Palawan Islands Group is the Strategic Environment Plan (SEP) for Palawan Act (RA 7611), which provides graded system of protection and control to the area. Environmentally Critical Areas Network (ECAN) serves as its main strategy. The ECAN among its many provisions shall ensure the following: conservation and protection of forest, watershed protection, preservation of biological diversity, protection and preservation of tribal culture, protection of the rare and endangered species and their habitat, provision of areas for environmental and ecological research, education and training, and the provision of areas for tourism and recreation. Thus, projects that support the objectives of SEP, in this case an REDD+ project, shall seek clearance from the Palawan Council for Sustainable Development (the mandated agency to implement the SEP Guidelines).

It is recommended that safeguards for REDD+ consider these existing safeguards to minimize duplication and reduce bureaucratic requirements for its implementation. 


\section{Concluding Remarks}

The Philippines forestry sector has been neglected for so long. Many sectors see REDD+ as a potential source of financing to implement a comprehensive forest conservation and development program in the country. There is a real danger that some sectors may view REDD+ finance as a panacea for all that ills the forestry sector. There is therefore a need to temper the enthusiasm with evidence-based information.

Review of the pioneering REDD+ projects in the Philippines revealed that external financial and technical support, local participation, free and prior informed consent, training of stakeholders, sustainability, national laws and policies, biodiversity conservation and safeguards are crucial in REDD+ development in the country. Since the country is in the early stage of adapting REDD+ projects, there are several challenges such as lack of funds and expertise, passive participation of the government, and conflicting interests with the local government plans. Hence, partnership with local funding institutions will be helpful to ensure the sustainability of REDD+ projects. Moreover, legal framework of REDD+ should be strengthened by national laws and policies to enhance links of local communities to various government and nongovernment agencies for REDD+ financing and collaboration. The limitations faced by the pioneering projects do not imply low potential of REDD+ in the country. The existence of national policies and programs such as Philippine Environmental Impact Statement System (PEISS), Community-Based Forest Management (CBFM), Philippine Strategy for Sustainable Development, Indigenous Peoples Rights Act, Wildlife Resources and Conservation Act, and Strategic Environmental Plan for Palawan Act could be a good starting point in the formulation of national REDD+ safeguards. Moreover, the active participation of the civil society, which has even led to the formulation of National REDD+ Strategy, has proven to be essential in the development of REDD+ initiatives in the country.

Learning from the pioneering projects can guide future REDD+ actions in the country. There are still several areas where information and experience are sorely lacking. First, there is still very limited information on baseline forest degradation rates. Biomass and carbon density surveys must be conducted to determine current levels as well as rates of accretion or decline. Second, reforestation and tree planting in the uplands have been slow to take off in the country due to numerous technical and governance reasons. Current REDD+ discussions have not included new and innovative ways to overcome these barriers. Business-as-usual set of strategies may simply repeat the failed experiences of forestry projects in the past. The Philippines has almost 100 years of reforestation experience but the country has not reaped much success. A review of reforestation in the Philippines showed that reforestation rate significantly lagged behind deforestation rate [58]. From 1960 to 2002, the annual average area planted is about 41,000 ha per year which is less than $50 \%$ of the annual deforestation rate for the same period. More importantly, the actual success rate of the reforestation effort could be less than $30 \%$ in many cases. Official statistics report the area planted for the year but do not track what portion still exists. This is validated by the fact that available maps do not show where the reforested areas are [59]. Third, there is very limited experience in the country in paying for an environmental service like carbon. How proceeds from carbon payments will be distributed to local communities must be carefully studied to avoid perverse social outcomes.

\section{Acknowledgments}

The authors are grateful for the support provided by the Alternatives to Slash and Burn (ASB) program and the Rewarding the Upland Poor for Environmental Services (RUPES) project in the preparation of this paper. They also want to thank Deutsche Gesellschaft für Internationale Zusammenarbeit (GIZ), Non-Timber Forest Products-Task Force (NTFP-TF), Fauna \& Flora International Philippines (FFI Philippines), and Conservation International (CI) Philippines for providing the information needed in writing the paper.

\section{References}

[1] K. L. Denman, G. Brasseur, A. Chidthaisong et al., "Couplings between changes in the climate system and biogeochemistry," in Climate Change 2007: The Physical Science Basis, S. Solomon, D. Qin, M. Manning et al., Eds., Contribution of Working Group I to the Fourth Assessment Report of the Intergovernmental Panel on Climate Change, Cambridge University Press, Cambridge, UK, 2007.

[2] R. T. Watson, I. R. Noble, B. Bolin, N. H. Ravindranath, D. J. Verado, and D. J. Dokken, Land Use, Land-Use Change, and Forestry, Published For the Intergovermental Panel For Climate Change, Cambridge University Press, Cambridge, UK, 2000.

[3] G. J. Nabuurs, O. Masera, K. Andrasko et al., "Forestry," in Climate Change 2007: Mitigation, B. Metz, O. R. Davidson, P. R. Bosch, R. Dave, and L. A. Meyer, Eds., Contribution of Working Group III to the Fourth Assessment Report of the Intergovernmental Panel on Climate Change, pp. 541-584, Cambridge University Press, Cambridge, UK, 2007.

[4] IPCC, Climate Change 2001: Impacts, Adaptation and Vulnerability, Summary for Policy Makers and Technical Summary of the Working Group II Report, World Meteorological Organization (WMO), Geneva, Switzerland, UN Environmental Programme (UNEP), Nairobi, Kenya, 2001.

[5] G. R. Van Der Werf, D. C. Morton, R. S. Defries et al., " $\mathrm{CO}_{2}$ emissions from forest loss," Nature Geoscience, vol. 2, no. 11, pp. 737-738, 2009.

[6] CDM Policy Dialogue, "Climate Change, Carbon Markets and the CDM: A call to action. Report of the High-Level Panel on the CDM Policy Dialogue," 2012, http://www.cdmpolicydialogue.org/report/rpt110912.pdf.

[7] G. B. Villamor and R. D. Lasco, "Rewarding upland people for forest conservation: experience and lessons learned from case studies in the Philippines," Journal of Sustainable Forestry, vol. 28, no. 3-5, pp. 304-321, 2009.

[8] UNFCCC, "Decision 1/CP.16-The Cancun Agreements: Outcome of the work of the Ad Hoc Working Group on Long-term Cooperative Action under the Convention," 2011, http://unfccc.int/resource/docs/2010/cop16/eng/07a01.pdf.

[9] A. La Viña, L. Ang, and J. Dulce, The Cancun Agreement: Do They Advance Global Cooperation on Climate Change? 
Foundation for International Environmental Law and Development, London, UK, 2011, http://www.field.org.uk/files/the _cancun_agreements__lavina_ang_dulce_0.pdf.

[10] N. Dano, "Clean development mechanism in the Philippines: promises and realities," in Confronting Climate Change: Unity of Grassroots Communities and Advocates For Action and Solidarity, Proceedings of the 1st Philippine National Grassroots Conference on Climate Change, Quezon City, Philippines, 2009.

[11] R. D. Lasco, R. S. Evangelista, and F. B. Pulhin, "Potential of community-based forest management (CBFM) to mitigate climate change in the Philippines," Small-Scale Forestry, vol. 9, no. 4, pp. 429-443, 2010.

[12] R. D. Lasco, F. B. Pulhin, L. A. Bugayong, and M. D. Mendoza, "An assessment of potential benefits to small holders of REDD+ components in the Philippines," Annals of Tropical Research, vol. 33, pp. 31-48, 2011.

[13] G. Bankoff, "One island too many: reappraising the extent of deforestation in the Philippines prior to 1946," Journal of Historical Geography, vol. 33, no. 2, pp. 314-334, 2007.

[14] R. D. Lasco, R. G. Visco, and J. M. Pulhin, "Secondary forests in the Philippines: formation and transformation in the 20th century," Journal of Tropical Forest Science, vol. 13, no. 4, pp. 652670, 2001.

[15] D. P. Garrity, D. M. Kummer, and E. S. Guiang, The Upland Ecosystem in the Philippines: Alternatives For Sustainable Farming and Forestry, National Academy Press, Washington, DC, USA, 1993.

[16] E. L. Boado, "Incentive policies and forest use in the Philippines," in Public Policies and the Misuse of Forest Resources, R. Repetto and M. Gillis, Eds., pp. 165-204, Cambridge University Press, New York, NY, USA, 1988.

[17] Forestry Development Center, Towards a Successful National Reforestation Program, Policy Paper No. 24, UPLB College of Forestry and Natural Resource, Laguna, Philippines, 1987.

[18] A. V. Revilla, Working Paper For the Forestry Policy Agenda For the Incoming Administration, College of Forestry and Natural Resources, University of the Philippines Los Baños, Laguna, Philippines, 1997.

[19] D. M. Kummer, Deforestation in the Post-war Philippines [Ph.D. thesis], Boston University, Boston, Mass, USA, 1990.

[20] T. M. Brooks, R. A. Mittermeier, G. A. B. Da Fonseca et al., "Global biodiversity conservation priorities," Science, vol. 313, no. 5783, pp. 58-61, 2006.

[21] H. Shi, A. Singh, S. Kant, Z. Zhu, and E. Waller, "Integrating habitat status, human population pressure, and protection status into biodiversity conservation priority setting," Conservation Biology, vol. 19, no. 4, pp. 1273-1285, 2005.

[22] M. R. C. Posa, A. C. Diesmos, N. S. Sodhi, and T. M. Brooks, "Hope for threatened tropical biodiversity: lessons from the Philippines," BioScience, vol. 58, no. 3, pp. 231-240, 2008.

[23] C. Hilton-Taylor, 2000 IUCN Red List of Threatened Species, IUCN, Gland, Switzerland, 2000.

[24] PAWB-DENR, "2004 Statistics on Philippine Protected Areas and Wildlife Resources," Protected Area and Wildlife (PAWB) website, Quezon City, Philippines, p. 249, 2004, http:// www.pawb.gov.ph/index.php?option=com_docman\&task=doc _details\&gid $=216 \&$ Itemid $=231$.

[25] PAWB-DENR, GEF and UNDP, "Barriers to Effective Protected Area Management in the Philippines," http://www .newcapp.org/about-philippine-biodiversity.php.
[26] Climate Change Commission (CCC), National Framework Strategy on Climate Change (NFSCC) 10 2010-2022, CCC, Manila, Philippines, 2010.

[27] The Philippines REDD-plus Strategy Team, “The Philippine National REDD-plus Strategy," Manila, Philippines, p. 97, 2010, http://www.elaw.org/system/files/PhilippineNationalREDDplusStrategy.pdf.

[28] Climate Change Commission, National Framework Strategy on Climate Change, 2010.

[29] Climate Change Commission, National Climate Change Action Plan, 2011.

[30] ITTO and FAO, Forest Governance and Climate Change Mitigation, Policy brief, 2009.

[31] Forest Carbon Partnership Facility (FCPF), Harvesting Knowledge on REDD+: Early Lessons From the FCPF Initiatives and Beyond, Facility Management Team (FMT) Working Paper 1, 2010.

[32] M. Poffenberger and K. Smith-Hanssen, "Forest communities and REDD climate initiatives," Asia Pacific Issues, no. 91, pp. 1$8,2009$.

[33] Meridian Institute, "Reducing Emission from Deforestation and Forest Degradation (REDD): An Options Assessment Report," Prepared for the Government of Norway by Arild Angelsen, Doug Boucher, Sandra Brown, Valerie Merckx, Charlotte Streck, and Daniel Zarin, 2011, http://www.redd-oar.org/ links/REDD-OAR_en.pdf.

[34] International Union for Conservation of Nature (IUCN), "REDD-plus explained," January 2011, http://www.iucn.org/ about/work/programmes/forest/fp_our_work/fp_our_work_ thematic/redd/redd_plus_explained/.

[35] Institute of Global Environmental Strategies (IGES), "Market Mechanisms Country Fact Sheet: The Philippines," Prepared by Akihisa Kuriyama for IGES Markting Mechanism Group, July 2012, http://enviroscope.iges.or.jp/modules/envirolib/upload/984/attach/philippines_final.pdf.

[36] A. M. Larson and E. Petkova, "An introduction to forest governance, people and REDD+ in Latin America: obstacles and opportunities," Forests, vol. 2, pp. 86-111, 2011.

[37] RECOFTC-The Center for People and Forest, ASEAN Social Forestry Network (ASFN) and Swiss Agency for Development and Cooperation (SDC), Community Forestry and Opportunities For REDD+ in the ASEAN Region, 2011.

[38] K. Herbertson, A. Ballesteros, R. Goodland, and I. Munilla, Breaking Ground: Engaging Communities in Extractive and Infrastructure Projects, World Resources Institute, 2009, http:// pdf.wri.org/breaking_ground_engaging_communities.pdf.

[39] M. M. Skutsch, P. E. van Laake, E. M. Zahabu, B. S. Karky, and P. Phartiyal, "Community monitoring in REDD+," in Realising REDD+: National Strategy and Policy Options, A. Angelsen, M. Brockhaus, M. Kanninen, E. Sill, W. D. Sunderlin, and S. WertzKanounnikoff, Eds., pp. 101-112, CIFOR, Bogor, Indonesia, 2009.

[40] J. P. Platteau and F. Gaspart, "The "elite capture" problem in participatory development," Center for Research on the Economics of Development (CRED), Faculty of Economics, Belgium, p. 40, 2003, http://crespienrico.files.wordpress.com/2008/11/elite-capture.pdf.

[41] J. Labonne and R. S. Chase, "Who is the wheel when communities drive development? Evidence from the Philippines," World Development, vol. 37, no. 1, pp. 219-231, 2009. 
[42] S. A. Fritzen, "Can the design of community-driven development reduce the risk of elite capture? Evidence form Indonesia," World Development, vol. 35, no. 8, pp. 1359-1375, 2007.

[43] A. Agrawal and A. Angelsen, "Using community forest management to achieve REDD+ goals," in Realising REDD+: National Strategy and Policy Options, A. Angelsen, M. Brockhaus, M. Kanninen, E. Sill, W. D. Sunderlin, and S. Wertz-Kanounnikoff, Eds., pp. 201-211, CIFOR, Bogor, Indonesia, 2009.

[44] A. Angelsen, M. Brockhaus, M. Kanninen, E. Sill, W. D. Sunderlin, and S. Wertz-Kanounnikoff, Eds., Eds.Realising REDD+: National Strategy and Policy Options, CIFOR, Bogor, Indonesia, 2009.

[45] Peskett, Leo, and A. Brockhaus, "When REDD+ goes national: a review of realities, opportunities and challenges," in Realising REDD+: National Strategy and Policy Options, A. Angelsen, M. Brockhaus, M. Kanninen, E. Sill, W. D. Sunderlin, and S. WertzKanounnikoff, Eds., pp. 25-43, CIFOR, Bogor, Indonesia, 2009.

[46] Secretariat of the Convention on Biological Diversity, "REDDplus and Biodiversity," CBD Technical Series 59, CDB, Montreal, Canada, 2011.

[47] PAWB-DENR (Protected Area and Wildlife BureauDepartment of Environment and Natural Resources), United Nations Development Programme (UNDP), Ateneo School of Government, and ASEAN Center for Biodiversity, The 4th Philippine National Report To the Convention on Biological Diversity: Assessing Progress Towards the 2010 Biodiversity Target, Philippine Clearing House Mechanism for Biodiversity, 2009, http://www.chm.ph/index.php?option=com_docman\& task=doc_details\&gid=171\&Itemid=112.

[48] A. Caparrós and F. Jacquemont, "Conflicts between biodiversity and carbon sequestration programs: economic and legal implications," Ecological Economics, vol. 46, no. 1, pp. 143-157, 2003.

[49] D. E. Bunker, F. DeClerck, J. C. Bradford et al., "Ecology: Species loss and aboveground carbon storage in a tropical," Science, vol. 310, no. 5750, pp. 1029-1031, 2005.

[50] I. Thompson, B. Mackey, S. McNulty, and A. Mosseler, Forest Resilience, Biodiversity, and Climate Change. A Synthesis of the Biodiversity/Resilience/Stability Relationship in Forest Ecosystems, Technical Series no. 43, Secretariat of the Convention on Biological Diversity, Montreal, Canada, 2009.

[51] J. F. Brodie, O. E. Helmy, W. Y. Brockelman, and J. L. Maron, "Bushmeat poaching reduces the seed dispersal and population growth rate of a mammal-dispersed tree," Ecological Applications, vol. 19, no. 4, pp. 854-863, 2009.

[52] F. Maisels, E. Keming, M. Kemei, and C. Toh, "The extirpation of large mammals and implications for montane forest conservation: the case of the Kilum-Ijim Forest, North-west Province, Cameroon," ORYX, vol. 35, no. 4, pp. 322-331, 2001.

[53] S. J. Wright, A. Hernandéz, and R. Condit, "The bushmeat harvest alters seedling banks by favoring lianas, large seeds, and seeds dispersed by bats, birds, and wind," Biotropica, vol. 39, no. 3, pp. 363-371, 2007.

[54] F. S. Chapin, E. S. Zavaleta, V. T. Eviner et al., "Consequences of changing biodiversity," Nature, vol. 405, no. 6783, pp. 234-242, 2000.

[55] D. Murphy, Safeguards and Multiple Benefits in a REDD+ Mechanism, International Institute for Sustainable Development (IISD), Manitoba, Canada, 2011.

[56] N. Moss and R. Nussbaum, "A review of three REDD+ safeguard initiatives," UN-REDD Programme and the Forest Carbon Partnership Facility publication, 2011, http://www.unredd.net/ index.php?option=com_docman\&task=doc_download\&gid= 5578\&Itemid $=53$.

[57] ASB and IISD, "Discussion paper on safeguards and co-benefits in a REDD+ mechanism," Workshop on Building REDD-plus Policy Capacity for Developing Country Negotiators and Land Managers, Hanoi, Vietnam, May 2011.

[58] U. Chokkalingam, A. P. Carandang, J. M. Pulhin, R. D. Lasco, R. J. J. Peras, and T. Toma, One Century of Forest Rehabilitation in the Philippines: Approaches, Outcomes and Lessons, Centre for International Forestry Research (CIFOR), Bogor, Indonesia, 2006.

[59] R. D. Lasco, "The reforestation value chain for the Philippines," in Smallholder Tree Growing For Rural Development and Environmental Services: Lessons From Asia, D. Snelder and R. D. Lasco, Eds., vol. 5 of Advances in Agroforestry, pp. 193-206, Springer, 2008.

[60] Forest Management Bureau, Philippine Forestry Statistics, Forest Management Bureau, Department of Environment and Natural Resource (FMB-DENR), Quezon City, Philippines, 2004. 

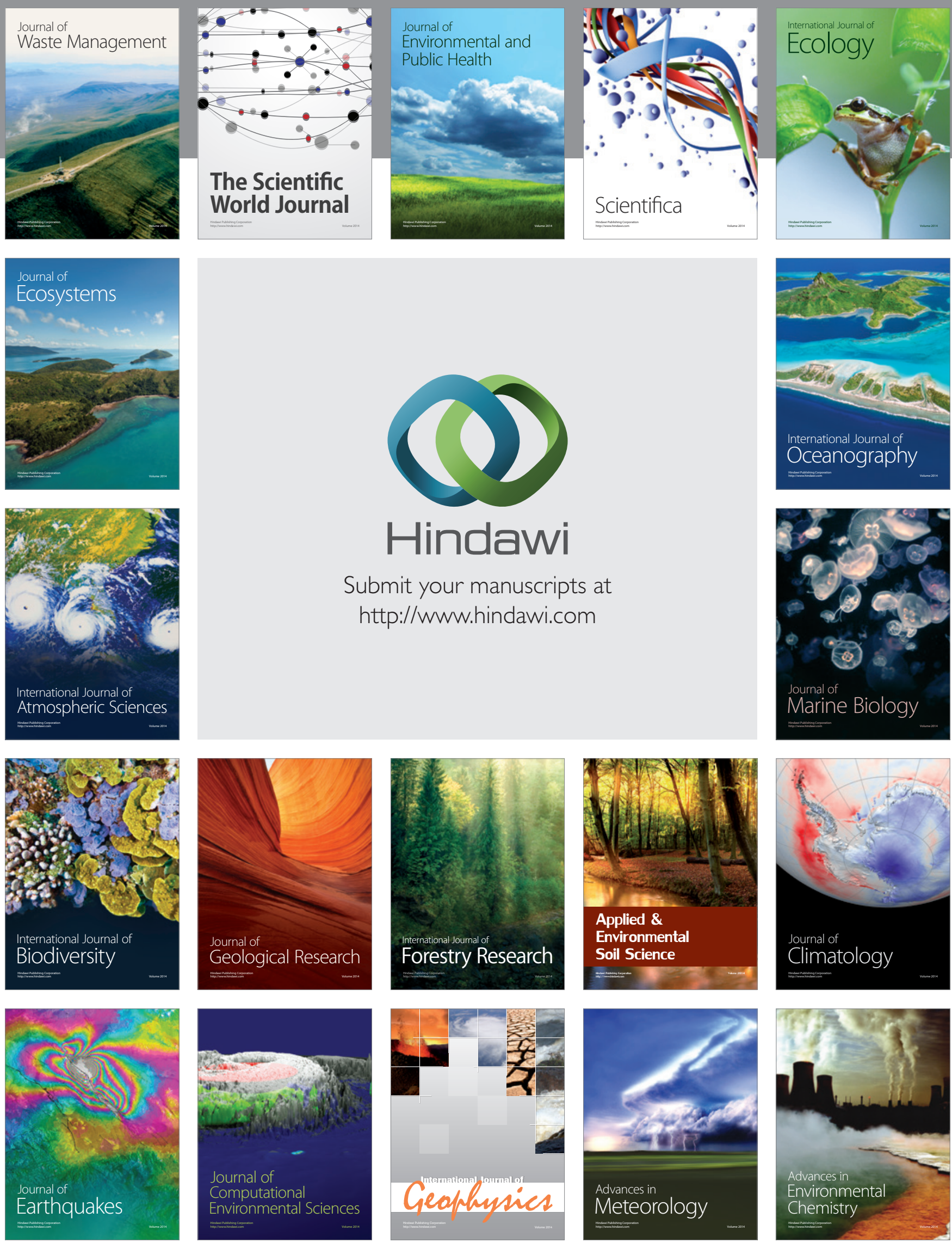